\title{
The impact of chronic pain on the quality of life and on the functional capacity of cancer patients and their caregivers
}

\author{
O impacto da dor crônica na qualidade de vida e na capacidade funcional de pacientes \\ oncológicos e de seus cuidadores
}

Juliana Martins Izzo¹, Ana Marcia Rodrigues Cunha², Claudia Bernardi Cesarino ${ }^{3}$, Marielza Regina Ismael Martins ${ }^{4}$

DOI 10.5935/2595-0118.20190062

\section{ABSTRACT}

BACKGROUND AND OBJECTIVES: Pain for cancer patients might represent a worsening prognosis, decreased autonomy, well-being and quality of life, affecting all spheres of life of cancer patients and their repercussions on caregivers. Therefore, this study aimed to evaluate the impact of chronic pain on the quality of life and functional capacity of cancer patients and their caregivers.

METHODS: Eleven caregivers and 15 cancer patients from a Pain Clinic were evaluated. To assess the functional capacity of the patients, we used the physical and instrumental activities of daily living scale and, for quality of life, we used the European Organization for Research and Treatment of Cancer Quality of Life Questionnaire (EORTC QLQ-C30), which indicated impairment in social and emotional functions and prevalence of symptoms fatigue and insomnia.

RESULTS: The average of the instrumental activities of daily living scores indicated a semi-dependence of the patients. There was a female predominance in patients $(60 \%)$ and caregivers $(72.2 \%)$. The average pain by the visual analog scale was 6.8 . The Zarit Caregiver Overload Scale indicated that $36.3 \%$ of caregivers had moderate to severe overload and a positive correlation between functional capacity and overload ( $\mathrm{p}=0.003)$.

Juliana Martins Izzo - (Dhttps://orcid.org/0000-0003-2174-2233;

Ana Marcia Rodrigues Cunha - Dhtps://orcid.org/0000-0001-9503-6337;

Claudia Bernardi Cesarino - Dhttps://orcid.org/0000-0002-8701-9163;

Marielza Regina Ismael Martins - (Dhttps://orcid.org/0000-0002-1140-7581.

1. Faculdade de Medicina de São José do Rio Preto, Acadêmica de Medicina, São José do Rio Preto, SP, Brasil.

2. Faculdade de Medicina de São José do Rio Preto, Hospital de Base, Clínica da Dor, Departamento de Anestesiologia, Săo José do Rio Preto, SP, Brasil.

3. Faculdade de Medicina de São Jose do Rio Preto, Curso de Pós-Graduaçáo em Enfermagem, Săo José do Rio Preto, SP, Brasil.

4. Faculdade de Medicina de Săo Jose do Rio Preto, Departamento de Ciências Neurológicas, São José do Rio Preto, SP, Brasil.

Submitted on July 23, 2019.

Accepted for publication on October 11, 2019.

Conflict of interests: none - Sponsoring sources: Bolsa de Iniciaçấo Cientifica /CNPq.

Correspondence to:

Avenida Brigadeiro Faria Lima 5416

Departamento de Ciências Neurológicas

15090-000 São José do Rio Preto, SP, Brasil.

E-mail: marielzamartins@famerp.br

(C) Sociedade Brasileira para o Estudo da Dor
CONCLUSION: The presence of chronic pain impacts, negatively and significantly, the quality of life and functional capacity of cancer patients extending this impact to the caregiver.

Keywords: Cancer pain, Caregivers, Quality of life.

\section{RESUMO}

JUSTIFICATIVA E OBJETIVOS: A dor para o paciente oncológico pode representar agravamento do prognóstico, diminuição da autonomia, do bem-estar e qualidade de vida, afetando todas as esferas da vida do paciente com câncer e sua repercussão no cuidador. Assim, este estudo objetivou avaliar o impacto da dor crônica na qualidade de vida e na capacidade funcional de pacientes oncológicos e de seus cuidadores.

MÉTODOS: Foram avaliados 11 cuidadores e 15 pacientes oncológicos de uma Clínica da Dor. Para avaliar a capacidade funcional dos pacientes foi utilizada a escala de atividades físicas e instrumentais da vida diária e, para a qualidade de vida, foi utilizado o European Organization for Research and Treatment of Cancer Quality of Life Questionnaire, que indicou prejuízo nas funçôes social e emocional e prevalência dos sintomas fadiga e insônia.

RESULTADOS: A média dos escores das atividades básicas e instrumentais da vida diária indicaram semi-dependência dos pacientes. Houve predominância feminina em pacientes $(60 \%) \mathrm{e}$ cuidadores (72,2\%). A média de dor pela escala analógica visual foi 6,8. A Escala de Sobrecarga do Cuidador de Zarit, indicou que $36,3 \%$ dos cuidadores apresentaram de moderada a grave sobrecarga e correlação positiva entre capacidade funcional e sobrecarga $(\mathrm{p}=0,003)$.

CONCLUSÁO: A presença de dor crônica impacta de forma negativa e significante a qualidade de vida e a capacidade funcional dos pacientes com câncer, estendendo esse impacto para a figura do cuidador.

Descritores: Cuidadores, Dor do câncer, Qualidade de vida.

\section{INTRODUCTION}

The World Health Organization (WHO) considers neoplasia-associated pain a worldwide medical emergency ${ }^{1}$. In oncology, it is one of the most frequent complaints and one of the most feared phenomena among patients with cancer. This becomes even more relevant as these patients face adverse emotional impact and discomfort at all stages of the disease, from diagnostic tests to conventional therapeutic procedures ${ }^{2}$. 
The multidimensional nature of oncologic pain is identified as Total Pain ${ }^{3}$. This conceptualization takes into account not only the dimension of physical suffering but also the emotional, social, and spiritual consequences of exposure to the experience of pain. The concept of Total Pain includes the assessment of physical aspects (injury and disease progression, and reaction to treatment), psychological aspects (depression, mood swings, apathy), social aspects (impaired social relationships, isolation and discouragement), and spiritual aspects (change in the relationship of individuals with their beliefs, principles and values, doubts about faith and the meaning of life, feelings of helplessness and hopelessness) ${ }^{3}$. About $50 \%$ of people with cancer experience pain during treatment, $10-15 \%$ of them with relevant intensity at an early stage $e^{4}$. With the onset of metastasis, the prevalence of pain increases by 25 to $30 \%$ and, in the advanced stages of the disease, from 60 to $90 \%$. Pain is the most common symptom of cancer in advanced stages ${ }^{2,4}$.

For the oncologic patient, pain may represent worsening prognosis or near death, decreased autonomy, decreased well-being, and quality of life, the threat of increased physical suffering, and a challenge to dignity. It can also harm cognitive functions, daily physical and social activities, the appetite, and sleep, which is interrupted by pain in $58 \%$ of the patients 5 .

The experience of chronic pain impacts not only patients but also people around them, like family members, friends, caregivers, and the team that treats them ${ }^{6}$. This experience has repercussions in the social, emotional, and spiritual aspects of life, such as restrictions on work and leisure activities, greater financial burden, psychological distress in the face of the discomfort of a loved one, and metaphysical questions, among others ${ }^{6.7}$.

Despite the high incidence in cancer patients, especially in patients on advanced stages of the disease, one of the biggest challenges is the fact that pain is still misdiagnosed. This is due to many factors, such as the lack of qualification for efficient handling by health professionals, who often underestimate or neglect patient pain, the use of ineffective assessment strategies, and patients' difficulty or reluctance in expressing their pain. Also, the lack of adherence is associated with the patient's concern about being hooked on analgesic drugs and the fear of their adverse effects ${ }^{8}$.

Thus, the present work is justified by the importance of elucidating the impacts of prolonged pain in all aspects of life of cancer patients and the impact on the caregiver, considering that the clarification of these impacts can be decisive for efficiency and patient's acceptance of the therapeutic procedures, as well as to promote physical and emotional well-being for the patient and those around him/her, including their caregivers.

\section{METHODS}

It is a cross-sectional, descriptive exploratory study, conducted at the Clinic of Pain Service of São José do Rio Preto Base Hospital. This study included patients diagnosed with chronic oncologic pain and their caregivers. The inclusion criteria of the patients were the presence of chronic pain lasting at least 6 months, and intensity greater than or equal to 3 (screened by the visual analog scale - VAS) ${ }^{9}$, and agree to participate in the study by signing the Free and Informed
Consent Term (FICT). Patients with limiting sensorial or cognitive deficits were excluded (screened by the Mini-Mental exam), or when refused to participate. For the caregivers, the inclusion criteria were taking care of a patient with chronic oncologic pain for at least 6 months, and accepting the caregiver FICT. Those who have refused to participate were excluded.

The following instruments have been used: a clinical and sociodemographic interview with patient and caregiver, as well as the physical and instrumental activities of the daily life scale $(\mathrm{OARS})^{11}$ to evaluate the functional capacity of both. The Quality of Life Questionnaire European Organization for Research and Treatment of Cancer Quality of Life Questionnaire (EORTC-QLQ-C30) ${ }^{12}$ was used to assess patients' quality of life, and the caregiver's burden was assessed with the Zarit Caregiver Burden Interview $(\mathrm{ZBI})^{13}$. The sample consisted of 15 patients and 11 caregivers, which was estimated by the sample calculation of $5 \%$ (error $=0.05)$ and with a reliability level of $95 \%(\alpha=0.05$ which provided $\mathrm{z} 0.05 / 2=1.96$ ), considering the true proportion as $50 \%(\mathrm{p}=0.50)$. The sample size was calculated based on the total number of patients undergoing clinical follow-up at the Pain Clinic of a teaching hospital, with a total of 20 patients/month with oncologic pain.

This study was approved by the FAMERP Human Research Ethics Committee, under protocol CAAE 86689518.8.0000.5415. The participation in the study was voluntary and made effective by signing the FICT. Participants were informed about their rights, according to Resolution 466/2012 of the National Health Council.

\section{Statistical analysis}

The Statistical Package for Social Science (SPSS) ${ }^{\circ}$ application was used. To achieve the proposed objectives, two statistical techniques were applied. The correlation analysis was performed using the Student test $t$, and the analysis of the EORTC QLQC30 instrument was performed according to the instructions provided by the group responsible for the standardization of the instrument in Brazil ${ }^{12}$.

\section{RESULTS}

Fifteen patients with chronic oncologic pain who were undergoing treatment at the Pain Clinic of the São José do Rio Preto Base Hospital were evaluated. Table 1 describes the sociodemographic and clinical characteristics of these patients.

About functional capacity for basic daily life activities, obtained by the "OARS" scale, the average scores can be observed in table 2.

Regarding instrumental activities, $60 \%(\mathrm{n}=9)$ of the participants reported being unable to clean and housekeeping, while $20 \%$ $(\mathrm{n}=3)$ claimed to need some help, and 20\% ( $\mathrm{n}=3)$ performed the task without help. In instrumental activities of daily living (IADL), there was a statistically significant difference $(\mathrm{p}=0.048)$, while in physical activities of daily living (PADL), this did not occur $(\mathrm{p}=0.052)$. When asked about activities as of shopping, $25 \%(n=4)$ had considered themselves incapable of performing, $60 \%(\mathrm{n}=9)$ need some help, and $15 \%(\mathrm{n}=2)$ do it without help (Figure 1). 
Note that the three symptoms with the highest scores were: fatigue (49.5), insomnia (37.4), and loss of appetite (30.6). By stratifying the group by gender, in table 3 , it was observed that female patients had better averages in overall health and role performance scales, while male patients presented better averages in cognitive function (Tables 3 and 4).

Caregivers also had their sociodemographic and clinical characteristics analyzed, as well as their overload and functional capacity for the basic activities of daily living (Tables 5 and 6).

In the correlation between age, IADL, PADL, and caregiver burden, in this data crossover, there was a positive correlation between them; that is, the older the person, the higher the perception of burden, the lower the IADL index $(p=0.003)$. There was no correlation between gender, PADL, and education $(p=0.75)$, because in these cases, there was no significant difference ( $p$-value $<0.05$ ) of overload among categories.

Table 1. Socioeconomic and clinical characterization of the study patients $(n=15)$

\begin{tabular}{|c|c|c|}
\hline Variables & $\%$ and $n$ & Mean \pm SD \\
\hline $\begin{array}{l}\text { Gender } \\
\text { Female } \\
\text { Male }\end{array}$ & $\begin{array}{l}60(n=9) \\
40(n=6)\end{array}$ & \\
\hline $\begin{array}{l}\text { Average age (years) } \\
\text { Female } \\
\text { Male }\end{array}$ & $\begin{array}{l}64.6 \pm 8.8 \\
54.8 \pm 7.7\end{array}$ & $60.7 \pm 9.5$ \\
\hline $\begin{array}{l}\text { Marital status } \\
\text { Single } \\
\text { Married } \\
\text { Widower } \\
\text { Separated }\end{array}$ & $\begin{array}{c}20(n=3) \\
53.4(n=8) \\
13.3(n=2) \\
13.3(n=2)\end{array}$ & \\
\hline $\begin{array}{l}\text { Education Level } \\
\text { Incomplete primary education } \\
\text { Complete primary education } \\
\text { Incomplete high school education } \\
\text { Complete high school education } \\
\text { Incomplete College }\end{array}$ & $\begin{array}{c}60(n=9) \\
13.3(n=2) \\
6.7(n=1) \\
13.3(n=2) \\
6.7(n=1)\end{array}$ & \\
\hline $\begin{array}{l}\text { Household income } \\
1 \text { to } 2 \mathrm{MW} \\
3 \text { to } 4 \mathrm{MW} \\
\text { Not reported }\end{array}$ & $\begin{array}{c}73.3(n=11) \\
6.7(n=1) \\
20(n=3)\end{array}$ & \\
\hline Drinker & $6.7(n=1)$ & \\
\hline Smoker & $6.7(n=1)$ & \\
\hline $\begin{array}{l}\text { How many times have you sought } \\
\text { the Emergency Service in the last } 6 \\
\text { months }\end{array}$ & & $\begin{array}{l}2.2 \pm 1.08 \\
\text { times }\end{array}$ \\
\hline $\begin{array}{l}\text { Average medical visits over the past } \\
12 \text { months }\end{array}$ & & $\begin{array}{l}3.4 \pm 0.9 \\
\text { times }\end{array}$ \\
\hline $\begin{array}{l}\text { Visual analog scale } \\
\text { Women } \\
\text { Men } \\
\text { Total }\end{array}$ & & $\begin{array}{l}7.1 \pm 1.9 \\
6.8 \pm 1.7 \\
6.8 \pm 1.9\end{array}$ \\
\hline $\begin{array}{l}\text { Has caregiver } \\
\text { Yes } \\
\text { No }\end{array}$ & $\begin{array}{c}66.6(n=11) \\
33.4(n=4)\end{array}$ & \\
\hline $\begin{array}{l}\text { Employment situation } \\
\text { Active } \\
\text { Inactive (retired) }\end{array}$ & $\begin{array}{l}60(n=9) \\
40(n=6)\end{array}$ & \\
\hline
\end{tabular}

$\mathrm{MW}=$ Minimum wage.
Table 2. Average scores of the physical and instrumental daily activity OARS of patients and caregivers

\begin{tabular}{|c|c|c|c|c|}
\hline Domains & Groups & $\mathrm{n}$ & Mean \pm SD & P-value \\
\hline \multirow{2}{*}{$\begin{array}{l}\text { Instrumental } \\
\text { of daily life }\end{array}$} & Patient & 11 & $9.54 \pm 3.44$ & \multirow[b]{2}{*}{$0.048^{*}$} \\
\hline & Caregiver & 7 & $13.4 \pm 1.5$ & \\
\hline \multirow{2}{*}{$\begin{array}{l}\text { Physical activity of } \\
\text { daily life }\end{array}$} & Patient & 11 & $12.45 \pm 1.86$ & \multirow{2}{*}{0.052} \\
\hline & Caregiver & 7 & $14 \pm 0.0$ & \\
\hline
\end{tabular}

* Statistically significant value $-\mathrm{p}>0.05$. Student's $t$-test.

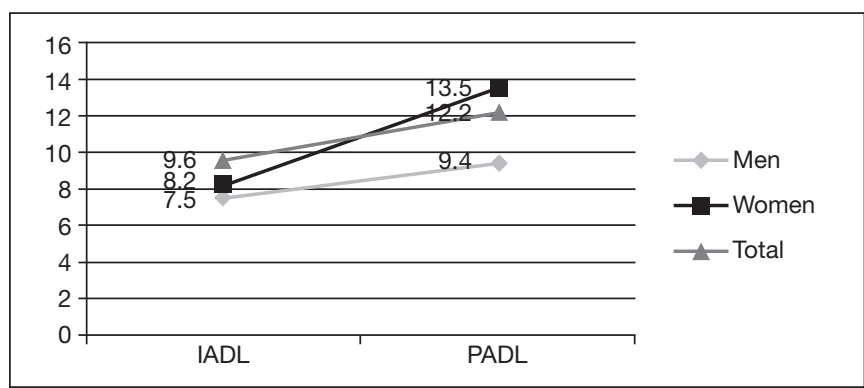

Figure 1. Average scores related to instrumental activities of daily living and physical activities of daily living

Table 3. Average and standard deviation ( \pm ) of the EORTC QLQ30 quality-of-life instrument scale scores of patients served at the Pain Clinic $(n=15)$

\begin{tabular}{lc}
\hline Functional Scales & \\
Physical function & $54.0 \pm 21.4$ \\
Role performance & $56.8 \pm 32.5$ \\
Emotional function & $53.7 \pm 15.5$ \\
Cognitive function & $72.4 \pm 23.9$ \\
Social function & $52.6 \pm 14.4$ \\
Symptom scales & \\
Fatigue & $49.5 \pm 19.8$ \\
Nausea/Vomiting & $19.1 \pm 12.4$ \\
Pain & $27.5 \pm 25.4$ \\
Dyspnea & $10 \pm 21.4$ \\
Insomnia & $37.4 \pm 22.5$ \\
Loss of appetite, & $30.6 \pm 13.9$ \\
Constipation & $22.0 \pm 16.4$ \\
Diarrhea & $12.5 \pm 23.8$ \\
Financial difficulties & $25.5 \pm 21.4$ \\
Quality of life overall health & $58.4 \pm 22.0$ \\
\end{tabular}

Table 4. Association between average quality of life scores and gender of patients $(n=15)$

\begin{tabular}{lcc}
\hline Scale items & Average \pm SD & P-value \\
\hline Quality of life overall health & & \\
$\quad$ Female & $62.4 \pm 12.2$ & $0.034^{*}$ \\
Male & $51.7 \pm 9.8$ & \\
Role performance & & \\
$\quad$ Female & $59.1 \pm 11.2$ & $0.042^{*}$ \\
$\quad$ Male & $49.8 \pm 10.5$ & \\
Cognitive function & & \\
$\quad$ Female & $62.8 \pm 9.9$ & $0.038^{*}$ \\
$\quad$ Male & $79.5 \pm 11.2$ & \\
${ }^{*}$ Chi-square test - $\mathrm{p}<0.05$ : a statistically significant difference. &
\end{tabular}


Table 5. Caregivers' socioeconomic and clinical characteristics $(n=11)$

\begin{tabular}{|c|c|c|}
\hline Variables & $\%$ and $\mathrm{n}$ & $\begin{array}{l}\text { Average and } \\
\text { SD ( } \pm \text { ) }\end{array}$ \\
\hline $\begin{array}{l}\text { Gender } \\
\text { Female } \\
\text { Male }\end{array}$ & $\begin{array}{l}72.2(n=8) \\
27.8(n=3)\end{array}$ & \\
\hline $\begin{array}{l}\text { Average age (years) } \\
\text { Female } \\
\text { Male }\end{array}$ & $\begin{array}{l}42 \pm 14.3 \\
64.3 \pm 4.9\end{array}$ & $\begin{array}{c}48.07 \pm 16.07 \\
\text { years }\end{array}$ \\
\hline $\begin{array}{l}\text { Marital status } \\
\text { Single } \\
\text { Married } \\
\text { Widower }\end{array}$ & $\begin{array}{c}17.9(n=2) \\
72.2(n=8) \\
9.9(n=1)\end{array}$ & \\
\hline $\begin{array}{l}\text { Education Level } \\
\text { Incomplete primary education } \\
\text { Complete primary education } \\
\text { Incomplete high school education } \\
\text { Complete high school education } \\
\text { Non-literate }\end{array}$ & $\begin{array}{c}27.2(n=3) \\
9.9(n=1) \\
16.7(n=2) \\
36.3(n=4) \\
9.9(n=1)\end{array}$ & \\
\hline $\begin{array}{l}\text { Household income } \\
1 \text { to } 2 \mathrm{MW} \\
3 \text { to } 4 \mathrm{MW} \\
\text { Not reported }\end{array}$ & $\begin{array}{c}72.2(n=8) \\
9.9(n=1) \\
16.9(n=2)\end{array}$ & \\
\hline $\begin{array}{l}\text { Drinker } \\
\text { Smoker }\end{array}$ & $\begin{array}{c}0 \\
9.9(n=1)\end{array}$ & \\
\hline $\begin{array}{l}\text { How many times have you sought the } \\
\text { Emergency Service in the last } 6 \text { months }\end{array}$ & & $\begin{array}{l}1.4 \pm 0.68 \\
\text { times }\end{array}$ \\
\hline $\begin{array}{l}\text { Average medical visits over the past } \\
12 \text { months }\end{array}$ & & $\begin{array}{l}2.7 \pm 1.0 \\
\text { times }\end{array}$ \\
\hline $\begin{array}{l}\text { Employment situation } \\
\text { Active } \\
\text { Inactive (retired) }\end{array}$ & $\begin{array}{l}63.7(n=7) \\
36.3(n=4)\end{array}$ & \\
\hline
\end{tabular}

Table 6. Average scores related to instrumental activities and physical activities of daily living, assessed by the "OARS" Scale and the overload of caregivers assessed by the Zarit scale $(\mathrm{n}=11)$

\begin{tabular}{lcc}
\hline Instruments & $\begin{array}{c}\text { Average } \\
\text { and SD }( \pm)\end{array}$ & $\%$ \\
\hline "OARS" Scale & & \\
Instrumental activity of daily life & $13 \pm 2.3$ & \\
Physical activity of daily life & $14,0 \pm 0$ & \\
Overload Scale - ZBI & & \\
Mild & & $63.7(\mathrm{n}=7)$ \\
$\quad$ Moderate & $18.15(\mathrm{n}=2)$ \\
$\quad$ Serious & & $18.15(\mathrm{n}=2)$ \\
\hline
\end{tabular}

\section{DISCUSSION}

The data indicate a $60 \%$ prevalence of women among patients seeking follow-up at the Pain Clinic services, versus $40 \%$ for men. The incidence of cancer between both genders is considered similar in developed countries, but in developing countries, such as Brazil, some studies have found a female prevalence of up to $25 \%$ higher ${ }^{14}$. In the analyzed sample, this difference reaches $50 \%$, which is aligned with the fact that care is not viewed as a male practice ${ }^{15}$.

Regarding the average age (60.7 years), the figures are in agreement with the data of the American Cancer Society, that is, $77 \%$ of cancers are diagnosed in individuals over 55 years. This higher average age is justified because aging is linked to the increased incidence of cancer due to various age-related physiological changes ${ }^{16}$.

Education data $(60 \%$ of patients had incomplete primary education) and income ( $72.2 \%$ of patients receive up to 2 minimum wages) are consistent with studies that indicate greater use of services of the Unified Health System (SUS) by the population with the lowest level of education and lower income. The higher probability of using SUS by individuals with lower education and lower per capita family income indicates that the public system assists groups with a more precarious social insertion, fulfilling expectations regarding the performance of this public policy ${ }^{17}$. Moreover, the low level of education present in this sample, also evident in other researches involving oncologic patients ${ }^{18}$, reveals a scenario of concern, as studies indicate that low education is related to late diagnoses and worse care standards to overall health, including resulting in higher mortality ${ }^{19}$. Regarding the VAS results, the average was 6.8 , indicating moderate to severe pain for patients. It is important to note that most patients undergoing treatment at the Pain Clinic routinely use one or more prescribed pain control drugs. Therefore, it is noteworthy that, despite the pharmacological treatment, the pain remained with significant intensity as a factor that aggravates the quality of life of these patients. Studies report that the non-control of pain may occur due to factors such as the potency of the analgesics used is lower than the pain intensity (negative pain control index), proposed analgesic schemes not compatible, or compatible with restrictions with the WHO analgesic scale pattern, or the incorrect use of drugs by patients, who use them only in situations of pain aggravation ${ }^{20}$.

Among the patients, $66.6 \%$ indicated that they have a person who acts as their caregiver. The importance of the caregiver in the health care of oncologic patients is essential. The caregiver provides direct care, such as drug administration, hygiene and food, and indirect care, accompanying the patient in all stages of the disease ${ }^{21}$.

Regarding functional capacity, the results obtained concerning IADL (such as using the telephone, taking transportation to travel, shopping, preparing meals, cleaning, taking drugs, and dealing with the finances) were 8.2 for women and 7.5 for men, on a scale from zero to 14 . According to the proposed classification, these numbers indicate an intermediate level of independence for IADL, a result supported by research that shows altered functional capacity in oncologic patients due to semi-dependence for activities of daily living, justified by abnormal performances in autonomy and independence 22 .

Still regarding functional capacity, the results obtained in relation to PADL (such as eating without help, dressing/ taking off clothes, personal hygiene, walking, lying/getting out of bed, taking a bath and getting to the toilet in time when needed) were 13.5 for women and 9.4 for men, on a scale from zero to 14 . Based on these numbers, women 
were considered to have a high degree of functional independence, while men had a significantly lower degree of independence.

No studies were found to support these findings and justify this less sensitive difference in IADL. However, contrary to the findings, some studies indicate that older women are usually more dependent on IADL than men ${ }^{23,24}$, with a lower quality of life $\mathrm{e}^{23,24}$ and a greater chance of incapacity ${ }^{25}$.

Regarding the quality of life, analyzed by the EORTC QLQ30 questionnaire, the social function was the most affected (52.6), followed by emotional (53.7), physical (54.0), performance of roles $(56.8)$, and finally cognitive $(72,4)$. These results were partially corroborated by the 2008 EORTC QLQ-C30 Global Benchmark Manual, in that cognitive function remains the least affected and emotional as the second most affected. Regarding symptoms, the three symptoms with the highest scores were: fatigue (49.5), insomnia (37.4) and loss of appetite (30.6). Again, these results were partially corroborated by the Benchmark Values Manual, which indicates the most frequent symptoms, in decreasing order, fatigue, insomnia, and pain.

Oncologic patients report fatigue as the most common symptom in all stages of the disease ${ }^{26}$. However, there is still no consensus on its definition, only on its multicausal nature $^{27}$. It is a very debilitating symptom that significantly limits daily activities and reduces working capacity. However, unlike other symptoms, especially pain, there are no known effective interventions for fatigue control and management, further increasing its disabling potential ${ }^{28}$.

When analyzed by gender, there was a statistically significant difference in QoL Overall Health scores (an average of 62.4 for women and 51.7 for men), role performance (59.1 for women and 49.8 for men), and cognitive function (62.8 for women and 79.5 for men).

A research focused on gender differences in cancer coping ${ }^{29}$ revealed significant results for understanding these differences observed in the present study. Men, faced with a diagnosis of cancer, assume a self-controlling attitude, suppressing emotional manifestations to fulfill their social problem-solving role. Perhaps this attitude is decisive for maintaining a higher score of the cognitive function of men compared to women. On the other hand, women adopt a more emotionally positive coping strategy, seeking social support and physical help to make the burden of the disease more bearable ${ }^{29}$.

Regarding the caregivers interviewed in this research, there was female prevalence $(72.2 \%$ are women, versus $27.8 \%$ men). The average age was 48 years ( 42 years for women, and 64.3 years for men). The prevalent marital status was married (72.2\% of respondents). Gender, age, and marital status data are corroborated by existing literature, which shows that adult and married women, usually wives, daughters, or sisters of the patient, make up the predominant profile of caregivers ${ }^{30}$.

This gender cut, specifically, matches with what studies attest to the social and cultural construction of which women have historically been the caregivers of their children, parents, and family ${ }^{31}$.

$72.2 \%$ of the caregivers had an income of up to 2 minimum wages, and $63.7 \%$ had an active work situation. These numbers indicate that the role of the caregiver may interfere with the individual's personal and family financial situation, contributing to an overload scenario. In Siegel's et al. ${ }^{28}$ study, $48 \%$ of caregivers had some sort of financial support, and $25 \%$ used their savings or borrowed money; Additionally, among the $79 \%$ of caregivers who were working, the main burden reported was financial.

Many caregivers need to abandon all or part of their work since they need, time after time, to accompany the patient to appointments or treatment sessions, or to give the patient full attention and care. In this sense, it is once more the women who end up prioritizing total dedication to caring, thus harming not only their professional activities but also their social life and leisure, resulting in a stressful overload of uninterrupted and daily care ${ }^{32.33}$.

Regarding the ZBI scale, results were mild overload for $63.7 \%$ of respondents, moderate for $18.15 \%$, and severe for $18.15 \%$. There was a positive correlation between age, IADL, and overload: the older the caregiver, the higher the perception of overload and the lower the IADL index. The Zarit Scale assesses, above all, the caregivers' subjective overload, that is, their perception of the situation. Thus, lower scores are common and present in other studies ${ }^{34}$. The explanation for this, as studies in psychology ${ }^{35}$ show, may be coping strategies related to controlling emotional reactions.

\section{CONCLUSION}

The set of results showed that the presence of chronic pain negatively and significantly impacts the quality of life and functional capacity of cancer patients. This impact is more significant in IADL, resulting in the semi-dependence of these patients, especially men.

It was also possible to conclude that this impact also extends to the figure of the caregiver. Older caregivers with relative functional disability showed a higher perception of overload.

\section{REFERENCES}

1. World Health Organization Collaborating Center for Policy and Communications in Cancer Care. Pain in children with cancer: The World Health Organization - IASP guidelines. Cancer Pain Relief. 1999;12(1).

2. Micu EC, Irsay L. The rehabilitation of oncological patients presenting neuropathies. Clujul Med. 2014;87(2):67-72.

3. Mendes TR, Boaventura RP, Castro MC, Mendonça MA. Ocorrência da dor nos pacientes oncológicos em cuidado paliativo. Acta Paul Enferm. 2014;27(4):356-61.

4. Bernard M, Strasser F, Gamondi C, Braunschweig G, Forster M, Kaspers-Elekes K, et al. SMILE consortium team. Relationship between spirituality, meaning in life, psychological distress, wish for hastened death, and their influence on quality of life in palliative care patients. J Pain Symptom Manage. 2017;54(4):514-22.

5. Graner KM, Costa Junior AL, Rolim GS. Dor em oncologia: intervençôes complementares e alternativas ao tratamento medicamentoso. Temas Psicol. 2010;18(2):345-55.

6. Almeida D, Silveira S, Godinho S, Zeferino M, Bortucan N. Palliative care: perception of caregivers of the elderly in cancer treatment. Rev Saude. 2017;43(2):55-62.

7. Lenza NDFB. Primeiro ano de pós-operatório: significado para a pessoa com estoma intestinal por câncer colorretal [dissertação de doutorado]. São Paulo (SP): Universidade de São Paulo; 2016. 
8. Costa W, Monteiro M, Queiroz J, Gonçalves AK. Pain and quality of life in breast cancer patients. Clinics. 2017;72(12):758-63.

9. Pimenta CAM. Escalas de avaliação de dor. In: Teixeira MD (ed.) Dor conceitos gerais. Săo Paulo: Limay; 1994. 46-56p.

10. Folstein MF, Folstein SE, McHugh PR. Mini-mental state. A practical method for grading the cognitive state of patients for the clinician. J Psychiatr Res. 1975;12(3):189-98.

11. Fillenbaum GG, Smyer MA. The development, validity, and reliability of the OARS Multidimensional functional assessment questionnaire. J Gerontol. 1981;36(4):428-34.

12. Fayers PM, Aaronson NK, Bjordal K, Groenvold M, Curral D, Bottomley A. On behalf of the EORTC Quality of Life Group. The EORTC QLQ-C30 Scoring Manual 3rd ed. 2016;17(4):750-7.

13. Brabo EP. Validação para o Brasil do questionário de qualidade de vida para pacientes com câncer de pulmâo QLQ LC 13 da Organizaçáo Europeia para a Pesquisa e Tratamento do Câncer [dissertação]. Rio de Janeiro (RJ): Universidade Estadual do Rio de Janeiro; 2006.

14. Pisani P, Bray F, Parkin DM. Estimates of the world-wide prevalence of cancer for 25 sites in the adult population. Int J Cancer. 2002;97(1):72-81.

15. Gomes R, Nascimento EF, Araújo FC. Por que os homens buscam menos os serviços de saúde do que as mulheres? As explicaçốes de homens com baixa escolaridade e homens com ensino superior. Cad Saúde Pública. 2007; 23(3):565-74.

16. Trinquinato I, Marques R, Ticona S, Betzabeth C, Antonietti C, Siqueira A. Gender differences in the perception of quality of life of patients with colorectal cancer. Investigación y Educación en Enfermería. 2017;35(3):320-9.

17. Teker F, Demirag G, Erdem D, Kemal Y, Yucel I. Quality of life in colorectal cancer patients during chemotherapy in the era of monoclonal antibody therapies. J BUON. 2015;20(2):443-51.

18. Nayak M, George A, Vidyasagar M, Mathew S, Nayak S, Nayak B et al. Quality of Life among Cancer Patients. Indian J Palliat Care. 2017;23(4):445-50.

19. Pinto FN, Barham EJ. Habilidades sociais e estratégias de enfrentamento de estresse: relaçấo com indicadores de bem-estar psicológico em cuidadores de idosos de alta dependência. Rev Bras Geriatr Gerontol. 2014;17(3):525-39.

20. Prado IS. Experiência de sintomas em homens com câncer: sintomas relacionados a estresse e qualidade de vida. 102F. [Dissertaçâo de mestrado em enfermagem]. Belo Horizonte (MG): Universidade Federal de Minas Gerais; 2010.
21. Knobf MT, Thompson AS, Fennie K, Erdos D. The effect of a community-based exercise intervention on symptoms and quality of life. Cancer Nurs. 2014;37(2):E43-50.

22. Saranath D, Khanna A. Current status of cancer burden: Global and Indian Scenario. Biomed Res J. 2014;1:1-5.

23. Pereira EE, Santos NB, Sarges ED. Avaliaçáo da capacidade funcional do paciente oncogeriátrico hospitalizado. Rev Pan-Amazônica de Saúde. 2014;5(4):37-44.

24. Borges E, Franceschini J, Costa L, Fernandes A, Jamnik S, Santoro I. Family caregiver burden: the burden of caring for lung cancer patients according to the cancer stage and patient quality of life. J Bras Pneumol. 2017;43(1):18-23.

25. Alves LC, Leite IC, Machado CJ. Fatores associados à incapacidade funcional dos idosos no Brasil: análise multinível. Rev Saúde Pública 2010;44(3):468-78.

26. Sanchez Kde O, Ferreira NM, Dupas, G, Costa DB. [Social support to the family of the cancer patient: identifying ways and directions]. Rev Bras Enferm. 2010;63(2):290-9.

27. de Araújo Lamino D, Turrini RN, Kolcaba K. Cancer patients caregivers comfort. Rev Esc Enferm USP. 2014;48(2):278-84.

28. Siegel K, Raveis VH, Houts P, Mor V. Caregiver burden and unmet patient needs. Cancer. 1991;68(5):1131-40.

29. Turkoglu N, Kilic D. Effects of care burdens of caregivers of cancer patients on their quality of life. Asian Pacific J Cancer Prev. 2013;13(8):4141-5.

30. Seima MD, Lenardt MH, Caldas CP. Care relationship between the Family caregiver and the elderly with Alzheimer. Rev Bras Enferm. 2014;67(2):233-40.

31. Cardona D, Segura A, Berberí D, Agudelo M. Prevalencia y factores asociados al síndrome de sobrecarga del cuidador primario de ancianos. Rev Fac Nac Salud Pública. 2013;31(1):30-9.

32. Rodrigues JE, Machado AL, Vieira NF, Fernandes AF, Rebouças CB. Qualidade de vida e sobrecarga de cuidadores familiares de idosos dependentes. Cienc Enferm. 2014;20(3):119-29.

33. Coppetti LC, Girardon-Perlini NMO, Andolhe R, Gutiérrez MGR, Dapper SN, Siqueira FD. Caring ability of family caregivers of patients on cancer treatment: associated factors. Rev Lat Am Enfermagem. 2018;26:e3048.

34. Furtado ME, Leite D. Cuidados paliativos sob a ótica de familiares de pacientes com neoplasia de pulmão. Interface. 2017; 21(63):969-80.

35. Chae J, Lee CJ, Jensen JD. Correlates of cancer information overload: focusing on individual ability and motivation. Health Commun. 2016;31(5):626-34. 